\title{
Labyrinthe
}

$11 \mid 2002$

Numéro 11

\section{France-Amérique : une généalogie du développement local}

\section{Pierre Dommergues}

\section{(2) OpenEdition \\ 12 Journals}

\section{Electronic version}

URL: http://journals.openedition.org/labyrinthe/648

DOI: 10.4000/labyrinthe.648

ISSN: 1950-6031

\section{Publisher}

Hermann

\section{Printed version}

Date of publication: 14 January 2002

Number of pages: 11-23

\section{Electronic reference}

Pierre Dommergues, «France-Amérique : une généalogie du développement local », Labyrinthe [Online], 11 | 2002, Online since 14 April 2005, connection on 03 May 2019. URL : http://

journals.openedition.org/labyrinthe/648; DOI : 10.4000/labyrinthe.648

This text was automatically generated on 3 May 2019.

Propriété intellectuelle 


\section{France-Amérique : une généalogie du développement local}

Pierre Dommergues 